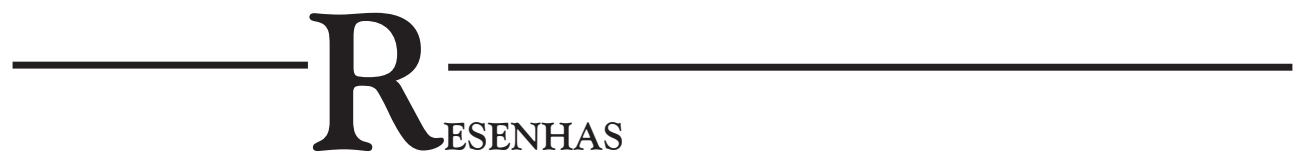

BÉRAUD, Céline; PORTIER, Philippe. Métamorphoses catholiques. Acteurs, enjeux et mobilisations depuis le mariage pour tous. Paris: Éditions de la Maison des sciences de l'homme, 2015, 205pp.

\title{
Mutações no Catolicismo: ATIVismo Religioso E MObilizaÇÕES POLÍTICAS
}

\author{
Lilian Sales* \\ *Universidade Federal de São Paulo \\ Guarulhos - São Paulo - Brasil
}

O livro de Céline Béraud e Philippe Portier Metamorphoses Catholiques tem como objeto as manifestações contrárias ao casamento civil entre pessoas do mesmo sexo ocorridas na França entre 2012 e 2013, quando o governo do presidente François Hollande enviou para votação a legislação que aprovaria o casamento e a adoção de crianças por casais homossexuais. A Igreja Católica foi um ator central na mobilização contrária a essa legislação, participando ativamente da organização de sete grandes manifestações públicas no país e demonstrando grande capacidade de mobilização. As manifestações contrárias ao "casamento para todos" tomaram as ruas de Paris e de outras cidades francesas e contaram com a presença de centenas de milhares de pessoas. 
No livro, os autores analisam o papel assumido pela Igreja Católica nessas mobilizações. Segundo eles, as manifestações contrárias ao "casamento para todos" marcaram o retorno do catolicismo no espaço público francês e demonstraram que, embora tenha deixado de ser a religião da maioria da população francesa ${ }^{1}$, ainda detém uma capacidade de mobilização surpreendente. Além disso, a grande mobilização em torno dessa questão aportou uma visibilidade inesperada ao catolicismo.

A partir da investigação desses episódios, os autores analisam as mutações em curso no universo católico, sendo esta a questão central da obra, presente desde seu título - Metamorfoses Católicas (ou no catolicismo). A obra traz uma interessante análise e investigação sobre a maneira de agir e de mobilizar da Igreja Católica nas últimas três décadas, demonstrando em torno de quais questões ela centra seu poder de criação e de disseminação de doutrinas, mas também sua capacidade de mobilizar no momento em que determinadas questões entram em debate nos cenários nacionais, como explicitou o caso das manifestações em torno do "casamento para todos" na França.

Para demonstrarem "metamorfoses no catolicismo", os autores retraçam as premissas da mobilização contrária ao casamento civil entre pessoas do mesmo sexo na França, retomando as suas origens, descrevendo os seus protagonistas, as alianças estabelecidas e as estratégias mobilizadas. Esse levantamento é realizado nos três primeiros capítulos do livro e fornece aos autores os elementos para as reflexões sobre as mudanças em curso no mundo católico, objeto do quarto capítulo da obra.

No primeiro capítulo, Béraud e Portier reportam-se aos primórdios das manifestações, retomando um conjunto de ideias e estratégias que foram criadas e disseminadas pela hierarquia do catolicismo a partir de meados da década de 1990 e que permitiram a emergência das manifestações contrárias ao "casamento para todos". Desde essa época, várias publicações oficiais do Vaticano passaram a abordar temas como as novas tecnologias reprodutivas, a bioética, o aborto e a eutanásia, o primeiro deles em 1968, sobre a contracepção artificial, e o último em 2008, a Instrução Dignitas Personae, em que discorre sobre as novas tecnologias reprodutivas. Seguindo essa tendência da alta hierarquia, a partir da década de 1990, os sacerdotes, especialmente bispos e teólogos, adotam um verdadeiro ativismo bioético, que se manifesta com maior força nos momentos em que esses temas eram abordados nos diversos países. $\mathrm{Na}$ França, o debate foi estabelecido desde a mesma década, quando foi votada a legislação sobre a bioética, que abrangia a reprodução assistida e o uso de células embrionárias em pesquisa.

As manifestações de 2012 e 2013 foram precedidas por três outras manifestações católicas na França: a oposição ao Pacs (união estável entre pessoas do mesmo sexo ou não), nos anos de 1998 e 1999; a querela em torno da abordagem de gênero nos manuais escolares fornecidos pelo Ministério da Educação, em 2011, e o ativismo bioético contrário a determinadas técnicas de reprodução assistida, na década de 1990. Os autores reconstituem as vias pelas quais se afirmam e se inventam as doutrinas em que esses combates estão inseridos, o que permite perceber que os três casos, e também as 
manifestações contrárias ao "casamento para todos", são combates pareados assumidos pela Igreja Católica. A grande batalha travada pela hierarquia católica desde meados da década de 1990, que parte do Vaticano e se reproduz nas conferências episcopais, diz respeito à família, ao gênero e à sexualidade, e também à bioética, sendo sobre esses temas que a Igreja Católica produz um grande número de textos oficiais, nos quais se utiliza da linguagem dos direitos dos homens e das ciências, apoiando, pois, suas doutrinas na razão pública. Entretanto, ela não enuncia sua palavra apenas por meio de documentos oficiais, mas também se ocupa de sua disseminação, seja pela sua rede territorial de paróquias e dioceses, seja em colóquios, blogs e em eventos para a formação de militantes. Assim, investe fortemente na produção e disseminação de concepções relativas a esses temas, que abrangem questões como o aborto, a eutanásia, o casamento homoafetivo, o uso de células embrionárias e a reprodução assistida.

No segundo e no terceiro capítulos, os autores observam esse ativismo em ação, desvendando os protagonistas da mobilização contrária ao "casamento para todos" e as suas estratégias de ação. Demonstram quem são os sacerdotes porta-vozes que conclamam os católicos a se manifestarem "enquanto cidadãos e membros de uma democracia participativa" (:77). Apontam o papel fundamental das alianças com as grandes associações católicas (como as associações de pais do ensino privado) e também com representantes de outras tradições religiosas: protestantes, judeus, ortodoxos e muçulmanos. Descrevem as lutas internas e indicam uma tendência à radicalização, disseminando o pânico moral sobre as questões relativas à família e à moral. Mostram também as resistências no interior do episcopado ligado ao "catolicismo de abertura". No que se refere às estratégias de mobilização, Béraud e Portier demonstram o repertório de ação: grandes marchas, pequenas manifestações diárias por toda a França, produção e circulação de textos e artigos. Afirmam o caráter reticular desses repertórios de ação, que se disseminam por todo o território francês, em suas paróquias e dioceses, mas também transnacionalmente, com laços fortes com movimentos cristãos americanos e movimentos internacionais que defendem causas semelhantes.

A partir desses dados, no quarto capítulo, os autores apontam a existência de uma nova configuração católica. A observação das manifestações contrárias ao casamento entre homossexuais traz três elementos-chave para a compreensão da configuração atual do campo católico.

O primeiro deles diz respeito a um rearmamento do catolicismo em torno das questões de gênero, bioética e dos direitos reprodutivos. Haveria um ativismo católico no que se refere a essas questões que não seria exclusividade do catolicismo francês. Pelo contrário, o episódio das manifestações contrárias ao "casamento para todos" traz à tona um catolicismo afirmativo, que já se organiza há mais de quinze anos no centro dos dispositivos de autoridade da Igreja Católica, em encíclicas, conferências episcopais, disseminando-se em dioceses e paróquias. Esse catolicismo afirmativo, em torno de um ativismo bioético e em relação às questões de gênero, vem sendo observado em outros países europeus, quando questões relativas a esses temas são colocadas 
nas pautas nacionais. Ainda segundo os autores, embora a batalha do casamento entre homossexuais tenha sido perdida, ela prossegue em outras arenas, como nas escolas, em uma constante vigilância aos manuais fornecidos pelo ministério da educação, por exemplo. Nesse campo, inclusive, ela obteve vitórias, conseguindo a suspensão de determinadas obras referentes às questões de gênero pelo ministério da educação francês.

A segunda constatação é a de que o catolicismo na França, apesar de representar uma minoria numérica, dispõe de importantes recursos organizacionais e capacidade de ação coletiva. Apresenta um grande dispositivo territorial (rede de dioceses e paróquias) que foi mobilizado durante as manifestações, meios financeiros que se apoiam na generosidade dos fiéis, um grupo de defensores de valores morais que se mobiliza a partir dos anos 1990 e um reservatório de militantes (em torno de associações de famílias católicas e também no ensino privado na França), relações midiáticas e políticas e a inscrição em redes de movimentos internacionais.

E, por fim, a persistência da diversidade interna ao catolicismo. Apesar das mobilizações e do investimento de parcela importante da alta hierarquia católica no ativismo bioético e antigênero, houve uma bipolarização do campo religioso católico francês em torno do "casamento para todos".

As duas primeiras constatações estão bastante bem fundamentadas ao longo da obra; já a terceira, sobre a divisão interna do catolicismo, se apresenta menos desenvolvida e consistente. $\mathrm{O}$ alinhamento de parcela importante dos representantes do catolicismo francês, principalmente no corpo episcopal, e grupos contrários ao "casamento para todos" encontra-se mais em evidência, e, embora esse posicionamento não represente a totalidade dos representantes do catolicismo na França, conforme colocado pelos autores, é ele que se mostra hegemônico ao longo das mobilizações sobre essa questão.

\section{Referências}

BÉRAUD, Céline; PORTIER, Philippe. Métamorphoses catholiques. Acteurs, enjeux et mobilisations depuis le mariage pour tous. Paris: Éditions de la Maison des sciences de l'homme, 2015, 205pp.

\section{Nota}

1 O número de adeptos ao catolicismo na França vem diminuindo significativamente. Embora tenha sido a religião da maioria dos franceses até por volta dos anos 80 do século XX, desde então o número de adeptos diminuiu vertiginosamente, não representando mais a religião da maioria.

Lilian Sales (lilian.sales@unifesp.br)

Professora adjunta de Antropologia da Universidade Federal de São Paulo (UNIFESP). Doutora em Ciência Social (Antropologia Social) pela Universidade de São Paulo (USP). 